\title{
The Role of Market Orientation and Learning Orientation in Improving Innovativeness and Performance of Small and Medium Enterprises
}

\author{
Suliyanto \\ Economics Faculty, Jenderal Soedirman University \\ Jl. HR. Boenyamin No. 708 Purwokerto, Indonesia \\ Tel: 62-28-163-7970 E-mail: suli_yanto@yahoo.com \\ Rahab \\ Economics Faculty, Jenderal Soedirman University \\ Jl. HR. Boenyamin No. 708 Purwokerto, Indonesia \\ Tel: 62-28-163-7970 E-mail: rahab_inc@yahoo.co.id
}

Received: April 25, 2011

doi:10.5539/ass.v8n1p134
Accepted: July 10, $2011 \quad$ Published: January 1, 2012

URL: http://dx.doi.org/10.5539/ass.v8n1p134

The research is financed by Post Graduate Program Jenderal Soedirman University

\begin{abstract}
The purpose of study is to describe contradiction relationship between market orientation toward organizational performance and to provide a quantitative analysis, in which learning orientation, market orientation, entrepreneurial orientation, and innovativeness function as the key success factors in technology-intensive firms. The authors formulate a structural equation model to examine the relationship among these constructs. A structural equation model was designed to examine the relationship. To test the model, the authors conducted covariance structural analyses of data collected from 150 small medium enterprises in Banyumas Regency. The central finding is that learning orientation plays a mediating role in the relationship between market orientation and innovativeness.

The results indicate that innovativeness has effect on business performance. Market orientation can strengthen learning orientation and innovativeness. In the small medium enterprises, the market information obtained from customers and competitors helps firms to keep an eye on the market. For better competitive advantages and business performance, firms must have learning capabilities and employees' identity with organizational mission. The findings indicate that firms should strengthen their learning orientation and innovativeness to improve business performance.
\end{abstract}

Keywords: Learning orientation, Market orientation, Innovation, Performance

\section{Background}

Small and medium enterprises (SMEs) demanded to develop market orientation concepts in their organizations in order to synchronize with the changing of business environment. Market orientation is a group of behaviors and processes or culture to create superior customer value (Narver and Slater, 1990; Keskin, 2006; Lin et al., 2008). Several previous studies indicated better performer in some companies when they focus on market orientation with particular emphasis on flexibility and speed of response (Noble et al., 2002; Lee and Tsai, 2005; Keskin, 2006; Lin et al., 2008).

Basically market orientation is the first step to response on environment business changing. Slater and Narver (1994) said that market orientation only gave impact on business performance when it was combined with learning orientation within of the company. Market orientation cannot positively influenced business 
performance without the ability of organization to use the information. Geus (1998) emphasize learning capability to learn faster from competitors for the sources of company competitive advantages. Baker and Sinkula (1999) argue the impact of market orientation and learning orientation synergy. They said a company with lower learning capability is supposed to be weak in market flexibility and less adaptive. Oriented learning company is not only gaining and spreading market information or using market knowledge to find a new way in customer service but also continuously able to investigate market development. Slater and Narver (1995) explain that maximizing business ability in market learning and creating market orientation become the beginning that requires further process in the form of ongoing learning process. Hardley and Mavondo (2000) ever mention that learning orientation has significant and positive impact on customers and competitors orientation. Based on the finding, the conclusion was then drawn that is level from learning orientation will influenced the relation between market orientation and business performance.

The other theory stated by Farrel (2000), learning orientation is the source of company competitive advantages. Therefore company should facilitate learning organization process as the main priority in business. Attitude and management action are suppose to facilitate learning and market orientation. Furthermore both of them essentially need the spirit of innovation. That idea is based on the understanding that market implementation relies on the company capability to distinguish either their product or market activity is one step forward than the competitors so that innovative attitude will be created. There is a positive impact of overall market orientation on insurance firms' innovation degree and innovation performance in both the US and EU markets (Nora-Lado and Olivares, 2001). Han et al (1998) in his research found that the nature of innovation provided a mediating relationship between market orientations and company performances.

A lot of research has been done in order to reveal whether market orientation created high performance in organization (Kara, 2005). Several results have also proven stronger relation between market orientation and organization performance (Matsuno et al., 1994, Greenley, 1995,1 Ghosh et al., 19944, Speed and Smith, 1993). In the other hand some of the researcher has revealed there is no such relation at all (Han et al. 1998, Jaworski and Kohli, 1993).

Study in management and marketing support the relations among market orientations, learning organization, innovativeness and performance. However, that relation in SMEs is still low. The relations significance of four variables in big company cannot be generalized for SMEs (Keskin, 2006). Therefore research to reveal relation among them in SMEs Should be done. This is aimed at examining the relations between market orientations and learning orientation as well as the impact on innovativeness improvement and SMEs performance. Based on that explanations the question researches are:

a. Does market orientation have an influence on the learning orientation of SMEs?

b. Does market orientation have an influence on innovativeness of SMEs?

c. Does market orientation have an influence on the performance of SMEs?

d. Does learning orientation have an influence on innovativeness of SMEs?

e. Does learning orientation have an influence on the performance of SMEs?

f. Does innovativeness have an influence on performance of SMEs?

\section{Literature Review and Hypothesis}

\subsection{Relations among market orientation, learning orientation and innovativeness}

Market orientation essentially relates by creating something new or different in responding market condition (Jaworski and Kohli, 1993). That statement is called as innovation. Han et al., (1998) and Hurley et al (1998) stated the innovation and successful of new product is a result of market penetration. They think that innovativeness is as a media of successful business in establishing organization knowledge and decision making process. Deshpande et al., (1993) found the influence of market orientation on company innovation. Kitchell (1995), reported about information investigation actively by organizations will create innovativeness. Slater and Narver (1994), viewed innovation as one of capabilities to create core value in supporting market orientation and company performance. Empirically Henard and Szymanski (2001) confirmed that market orientation contributed to the success of new product.

Sinkula et al., (1997) states that learning orientation described the view of the importance of learning within the organization. Organizations that have a high degree of learning will have a strong commitment to learning (Sinkula et al., 1997). The degree of learning orientation can be reflected from the view of the importance of learning within the organization (Sinkula et al., 1997). The learning process plays an important role in the new 
paradigm theories of competitive advantage (Hunt and Morgan, 1995). However, Sujan et al., (1994) stated that learning is viewed as an investment that will provide long-term benefits from the short term, so companies rarely to practice this development.

Concerning about the relation between learning orientation and innovativeness, Dickson (1996), stated that a good learning environment in organization will improve the using of company resources effectively. Furthermore stated Mulen and Lyles (1993), stated that orientation in organizational learning simultaneously will improve efficiency and effectiveness of the company innovation activity. Companies are supposed to force employee to absorb knowledge continuously and manage internal knowledge system when it becomes the key factor that is able to combine learning organizations and innovation activity (Drucker, 1993).

The other argument by Hult et al. (2004) explain that learning orientation will occur in company culture level and there is probability to be mediated by the factors that have direct influence to business performance. Argyris and Schon (1978) as well as Fiol and Lyes (1985) stated that learning orientation will create a new behavior and finally influence the improvement of business performance. Sinkula (1994) defined learning as knowledge addition to improve level of it. Calatone et al. (2002) showed the relations between learning innovation orientation and business performance. Learning orientation is believed to be one of key factors of market orientation and innovativeness (Zhang et al., 2004). It has also significant impact to organization performance.

In a relation with the connection between market orientation and learning orientation, learning orientation mean organizational capability opposing classic assumption on market. Market orientation means organization focus to environment changing that impacted to the ability to maximize consumer satisfaction (Hardley and Mavando, 2000). The major differentiation both of the concepts is learning organizational using their knowledge based on the market to improve consumer satisfaction (Mavondo, 2000). In 1993 Dogdson implied that learning organization able to facilitate external trade out process in company effectively. For example, consumer preference and technology of product. The improvement of learning capability will increase probability of one company to absorb and implement a new knowledge (Cohen and Levinthal, 1990). Hurley and Hult (1998) viewed that learning orientation as a fundamental to build innovation oriented culture.

Farrel (200) as well as Slater and Narver (1995) stated, market oriented organization will provide culture frame from learning orientation to be developed by company. Baker and Sinkula (1999) stated that market orientation will facilitate adaptive learning for company. In extreme condition learning organizational is the fundamental market orientation, because the approach directed on the market can appear when companies learn to learn (Day, 1994). Learning organization and market orientation are interdependent. According to explanations the hypotheses are:

H1: Market Orientation has positive influence on learning orientation

$\mathrm{H} 2$ : Market orientation has influence on innovativeness

H3: Learning orientation has positive influence on innovativeness

\subsection{Relation among market orientation, learning orientation, innovativeness and business performance}

Innovation is the changing in organizations. It is response to adapt from environment changing or as an effort to anticipate environment influence, and reach competitive advantages as well as company performance improvement (Hult et al., 2004). Administrative innovation practice can be integrated into business operation models in order to improve business performance (Han et al., 1998).

Bharadwaj et al., (1993) suggested that the company's ability to continue innovating on its products will keep the product remains in accordance with the wishes and needs of customers. Verhess and Meulenberg (2004) states that product innovation has a positive relationship with a variety of product appeal. According to Slater (1997) companies who use the benefits of differentiation and cost advantage will continuously creates added value for customers, in both short and long term, so the relative performance of the company will be better than its competitors through customer satisfaction and loyalty .

Market orientation is a group of behavior and activity as a basic of decision making or part of organizational culture (Hurley and Hult, 1998). Generally market orientations have positive influence to company performance (Despahande, 1999; Pelham, 2000; Behesti, 2004 and Bose, 2004). In 2004 Verhees and Meulenberg examine relations between market orientation and company performance with innovation treatment as instrumental variable. The result indicates that market orientations have influence to company the performance improvement. Some researchers conclude that market orientations can be influenced directly on business performance or indirectly through innovations. 
Furthermore a company with high level learning orientations will trigger its employees to be innovative (Perrin and Sampaio, 2003). On the other hand it will lead company development to supreme performance (Hurley and Hult, 1998). Therefore market orientations and learning orientations will influence directly to business performance or indirectly trough innovations. Based on that ideas author present the following hypothesis:

H4: Market orientation has positive influence on business performance

H5: Learning orientation has positive influence on business performance

H6: Innovativeness has positive influence on business performance

\section{Methodology}

\subsection{Research Design}

Quantitative approach was used in this research. It is confirmatory research; because this research begins with hypothesis or questions research and involve an exact procedure and specific data sources (Hartono, 2004). Data collection was conducted by survey. Based on time dimension, this research was included in since it was done once (Hartono, 2004). Unit analysis of this study is SMEs.

The population is SMEs in Banyumas regency. The sampling method is non probability sampling with convenience sampling method. The amount of samples is 200 companies. Those numbers already fulfil the requirements of minimum sample to be analyzed with SEM (Structural Equation Modeling) that is five observations for each parameter estimation. For this research the amount of the estimation is 30 so minimum samples is 150 . We used prime source directly from research resources (Cooper and Schinder, 2006). Data collection was obtained from survey by spreading questioner to the owner of SMEs in Banyumas regency. It was done on September until November 2010.

\subsection{Measurement and Data Analysis}

Market orientation is company orientation related to the effort to follow market sense and consumer needs in process production (Narver and Slater, 1990; Lin et al., 2008). This variable is measured by 15 questions divided into three categories, they are: competitor oriented, consumer oriented and function intern coordination. Learning orientation is the way of company to commit in problem solving systematically (Slater and Narver, 1995; Calantole, 2002; Lin et al, 2008). Innovativeness here means openness mind for new ideas that becomes a part of organization culture related to willingness to run business. This variable was measured by 5 questions adopted from: Calontone et al, 2002; Keskin, 2006 and Lin et al. 2008. Performance comes from company operations (Lin et al. 2008). Company performance scale measurement was adopted from Keskin, 2006 and Lin et al. (2008). Research subject come from every SMEs with different field. Therefore company performance measurement used relative performance measurement: market share growth, sales growth and profitability (Calonte et al. 2002; Keskin, 2006; Lin et al; 2008). Variable measurement instrument used data interval measurement which is refinement of semantic scale that we expect the result is internally scaled data (appendix 1), with the process by putting two extreme categories (Ferdinand, 2005). To examine model and hypothesis Structural Equation Modelling (SEM) Analysis was used.

\section{Results}

\subsection{Validity and Reliability Test}

Based on confirmatory analysis, thirteen indicators in the market orientation variables and seven indicators on the organizational learning variables have factor loading above 0.5 so that all the indicators in those variables were valid. (Hair et al., 1998). The fifth indicator of the five indicators on innovativeness variables and fifth indicators of the six indicators on business performance variable have a factor loading below 0.5 thus these indicators were not valid and should be excluded from the analysis. Based on the value of variance extract all variables above 0.5 , and construct reliability above 0.7 so that all variables were reliable (Table 1 )

\subsection{Goodness of Fit Model}

Testing empirical model is only able to meet criteria on adequate of fit, with a value of Chi-square $=1165.553$, probability $=0.000, \mathrm{RMSEA}=0120, \mathrm{GFI}=0.638, \mathrm{AGFI}=.575, \mathrm{Cmin} / \mathrm{DF}=3.142, \mathrm{TLI}=0.770, \mathrm{CFI}=0.790$, and GFI $=.638$. Goodness-fit value, can be increased based on the modification index output result, if done the covariance between the error is done it will lower the value of chi-square test. (but the linking error must be explained by theory.) Researchers do not employ revision model, because based on the analysis of modification index, covariance relationships among variables have been reviewed theoretically. 


\subsection{Hypothesis Test and Discussion}

Hypothesis test was done by using Structural Equation Modelling (SEM) of which results are listed in Figure Based on figure 1 explained the path coefficient value. Path coefficients and significance can be seen in table 2 .

Based on table 2, it shows the path coefficient variable of learning orientation to learning is 0.767 . It means there is a positive influence on the variables of market orientation to learning orientation, or the better market orientation, the learning orientation will also be better. The nature of these positive effects are significant, this is indicated count value $\mathrm{CR}=5.564$. $\mathrm{CR}$ count value is higher than the $\mathrm{CR}$ table (table $\mathrm{t}$ ) at the 95 percent of confidence level (one end). Therefore first the hypothesis which state market orientation has a positive effect on learning orientation is accepted.

The results are supported by the research of Farell (2000), Slater and Narver (1995) which stated that a market-oriented organization will provide a cultural framework of learning orientation that can be developed by the company. Besides, this research is also supported by the Zhang et al., (2004) who explained that learning orientation is one of the key factors for market orientation and innovativeness. This research also has the same idea with Baker and Sinkula (1999) when they stated that market orientation will facilitate adaptive learning for the company. Indirectly this research also in accordance with the Bel et al., (2002), Baker and Sinkula (2002) stated that organizational learning and market orientation are interdependent and mutually synergized.

Path coefficient of market orientation variable to innovativeness is 0.413 . It means there is a positive influence of market orientation to innovativeness variable, or the better of the market orientation, the better innovativeness will be. The nature of these positive effects are significant, as indicated on CR value $=4.022$. CR count value is higher than the CR table (table t) at the 95 percent of confidence level (one end). Therefore second hypothesis market orientations have an influence on innovativeness is accepted.

The results were also supported by Jaworski and Kohli (1993) statement in which market orientation is essentially connected with creating something new or different in response to market conditions. In the other hand research Deshpande et al., (1993) who found the effect of market orientation on company innovation have same perception with the result. Moreover it is also consistent with Kitchell (1995) which stated that the search information proactively made the organization will produce innovativeness organization concerned. Clearly it is supported by research of Hernard and Szymanski (2001) that empirically confirmed that the market orientations contribute to the success of the company's new product.

Path coefficient of learning orientation variable to innovativeness is 0.445 . It means there is positive effect from a learning orientation to innovativeness variable, or the better the learning orientation, the better innovativeness. The nature of these positive effects are significant, as indicated count value $\mathrm{CR}=3.786$. CR count value is higher than the CR table (table $\mathrm{t}$ ) at the 95 percent of confidence level. Therefore the third hypothesis stating that learning orientation has a positive influence on innovativeness is accepted.

The results are supported by the research of Dickson (1996) which stated that a good learning environment in the organization will improve the effectiveness of using all the resources companies, including activities for market orientation and innovation. Moreover it is also supported by Mulen and Lyles research (1993) which stated that organizational learning orientation continuously will improve the efficiency and effectiveness of corporate innovation activities. Firmly it also consistent with research of Perin and Sampaio (2003) which stated that company with high levels of learning orientation will encourage employees to innovate. This research also supports the research of Hurley and Hult (1998) which stated that learning orientation will lead the development of the company on the superior performance.

Path coefficient of market orientation variable to business performance is 0.229 . It means there is no positive effect on the variables of market orientation to business performance. The nature of these positive effects are not significant, indicated by value of $C R$ count $=1.840$. CR count values are lower than the $\mathrm{CR}$ table ( $\mathrm{t}$ table) at 95 percent of confidence level. Therefore fourth hypothesis which states the level of the company's market orientation has a positive influence on business performance is rejected.

The result did not support the research conducted by Farell (2000), Slater and Narver (1995) which stated that a market-oriented organization will provide a cultural framework of learning orientation that can be developed by the company. Moreover it also contradict the research by Deshpande, 1999; Pelham, 2000; Behesti, 2004; Bose, 2004 declaring the market orientation has a positive influence on the performance of both large and small companies.

The difference results of this research can be explained that market orientation is unable to directly improve business performance without innovation variable as a media. Besides it can improve business performance 
when it is integrated with organizational learning as proposed by Bell et al., (2002) and Baker and Sinkula (2002) stated that organizational learning and market orientation are interdependent and mutually synergized.

Verhees and Meulenberg (2004) examine the relationship between market orientation and company performance with the treatment of innovation as an instrumental variable.

Path coefficient of learning orientation variable to business performance is 0.123 . It means there is no positive effect of variable orientation learning to business performance. The nature of these positive effects is not significant, as indicated count value $\mathrm{CR}=0.985$. CR count values are lower than the $\mathrm{CR}$ table ( $\mathrm{t}$ table) at 95 percent of confidence level. Therefore the fifth hypothesis which states levels of learning orientation has a positive influence on company business performance is rejected.

Declination of this hypothesis can be explained that the learning organization cannot directly improve the performance of the organization but it must go through other variables that may intervene between organizational learning with business performance, as stated by Hult et al., (2004) stating that learning orientation occurs especially at the level of corporate culture and possibilities to be mediated by factors that impact directly on business performance. Then Calantone et al., (2002) states that the connection between innovation learning orientation and business performance. Learning orientation is one of the key factors of market orientation and innovativeness (Zhang et al., 2004). In line with Dodgson (1993) stating that learning orientation is able to facilitate the company for effectively external exchanges, such as consumer preferences, product technology. The increase of learning capability will absorb and assimilate new knowledge (Cohen and Levinthal, 1990). Hurley and Hult (1998) viewed that learning orientation is as a pioneer to build a culture that leads to innovation.

Path coefficient of innovativeness variable to business performance is 0.387 . It means there is a positive influence of innovativeness to business performance. The nature of these positive effects are significant, as indicated by count value $\mathrm{CR}=3.091$. It is higher than the $\mathrm{CR}$ table (table $\mathrm{t}$ ) at the 95 percent of confidence level. Therefore the sixth hypothesis that states the level innovativeness companies have a positive influence on business performance is acceptable.

The results support the research of Hult et al., (2004) who found that innovation means a change in the organization. Innovation is a response to adapt from environmental changes or as an effort anticipated to affect the environment, and achieve competitive advantage and improved company performance. Besides, it also supports the research of Han et al., (1998) arguing that both the administrative innovations and technical can be integrated into business operations model to improve business performance.

\section{Conclusions and Recommendation}

Market orientation has a positive effect on learning orientation and innovativeness SMEs, whereas learning orientation influence to innovativeness. Innovativeness has a positive impact on business performance. Recommendations To improve the business performance of Small and Medium Enterprises (SMEs) should always increase the degree of market orientation by gathering customer information, competitor information and continuously make coordination among functions; it is because market orientation is proven to encourage learning orientation and innovativeness, it can be a source of advantages for SMEs to improve business performance.

\section{Limitation and Future Research}

This research has limitations on the level of model accuracy that is still low (marginal). Since the respondents have different background both in the SME business sector and educational background, the answer becomes very heterogeneous. Future research should be done by selecting more homogeneous subjects and involving moderating competitive environment variables.

For future research, it can be conducted on SMEs with the same type of industry in order to improve the accuracy of the model. However, it can also be done by adding variable business environment and company size as a moderating variable.

\section{References}

Baker, W.E. and Sinkula, J.M. (1999). The synergistic effect of market orientation and learning organization and organizational performance. Journal of the Academy of Marketing Science, Vol. 27, No. 3, pp. 411-27. http://dx.doi.org/10.1177/0092070399274002

Baker, W.E. and Sinkula, J.M. (2002). Market orientation, learning orientation and product innovation: delving into the organization's black box. Journal of Market-Focused Management. Vol. 5, No. 1, pp. 5-23. 
http://dx.doi.org/10.1023/A:1012543911149

Beheshti, H.M. (2004). Gaining and sustaining competitive advantage with activity based cost management system. Industrial Management \& Data Systems, Vol. 104, No. 5, pp. 377-383. http://dx.doi.org/10.1108/02635570410537462

Bell, S.J., Whitwell, G.J. and Lukas, B.A. (2002). Schools of thought in organizational learning. Journal of the Academy of Marketing Science, Vol. 30, No. 1, pp. 70-86. http://dx.doi.org/10.1177/03079459994335

Bharadwaj, Sundar G.; Varadarajan, P. Rajan \& Fahy, John. (1993). Sustainable Competitive Advantage in Service Industries: A Conceptual Model and Research. Journal of Marketing, Vol. 57, No. 4, pp. 83-90. http://dx.doi.org/10.2307/1252221

Bose, R. (2004). Knowledge management metrics. Industrial Management \& Data Systems, Vol. 104, No. 6, pp. 457-68. http://dx.doi.org/10.1108/02635570410543771

Calantone, R.J., Cavusgil, S.T. and Zhao, Y. (2002). Learning orientation, firm innovation capability, and firm performance. Industrial Marketing Management, Vol. $31, \quad$ No. $6, \quad$ p. 515 . http://dx.doi.org/10.1016/S0019-8501(01)00203-6

Cohen, W.M. and Levinthal, D.A. (1990). Absorptive capacity: a new perspective on learning and innovation. Administrative Science Quarterly, Vol. 35, No. 1, pp. 128-52. http://dx.doi.org/10.2307/2393553

Day, G.S. (1994). The capabilities of market-driven organizations. Journal of Marketing, Vol. 58, No. 4, pp. 37-52. http://dx.doi.org/10.2307/1251915

Deshpande, R. (1999). Foreseeing' marketing. Journal of Marketing, Vol. 63, pp. 164-7. http://dx.doi.org/10.2307/1252109

Deshpande, R., Farley, J.U. and Webster, F.E.J. (1993). Corporate culture, customer orientation, and innovativeness. Journal of Marketing, Vol. 57, No. 1, pp. 23-7. http://dx.doi.org/10.2307/1252055

Dickson, P.R. (1996). The static and dynamic mechanics of competition: a comment on Hunt and Morgan's comparative advantage theory. Journal of Marketing, Vol. 60, No. 4, pp. 102-6. http://dx.doi.org/10.2307/1251904

Dodgson, M. (1993). Organizational learning: a review of some literatures. Organization Studies, Vol. 14, No. 3, pp. 375-94. http://dx.doi.org/10.1177/017084069301400303

Farrell, M.A. (2000). Developing a market-oriented learning organization. Australian Journal of Management, Vol. 25, No. 2, pp. 201-23. http://dx.doi.org/10.1177/031289620002500205

Ferdinand, Augusty. (2005). Structural Equation Modeling Dalam Penelitian Manajemen. Badan Penerbit Universitas Diponegoro Semarang.

Fiol, C.M. and Lyles, M.A. (1985). Organizational learning. Academy of Management Review, Vol. 10, No. 4, pp. 803-813.

Geus, A.P.D. (1998). Why some companies live to tell about change. The Journal for Quality and Participation, Vol. 21, No. 4, pp. 17-21.

Ghosh, B. C., H.P. Schoch, D.B. Taylor, W. W. Kwan and T.S. Kim, (1994). Top Performing Organization of Australia, New Zealand and Singapore: Comparative Study of Their Marketing Effectiveness. Marketing Intelligence and Planning, Vol. 12, No. 7. pp. 39-48. http://dx.doi.org/10.1108/02634509410065519

Greenley, G. (1995). Market Orientation and Company Performance: Empirical Evidence From UK Companies. British Journal of Management, Vol. 6, No. 1. pp. 1-13. http://dx.doi.org/10.1111/j.1467-8551.1995.tb00082.x

Hair, Joseph, F., Anderson, Rolpp, E. Tatham, Ronald, L and Black, William, C. (1998). Multivariate Data Analysis. Third Edition. Prentice Hall.

Han, J.K., Kim, N. and Srivastava, R.K. (1998). Market orientation and organizational performance: is innovation a missing link? Journal of Marketing, Vol. 62, No. 4, pp. 30-45. http://dx.doi.org/10.2307/1252285

Hardley, F. and Mavondo, F. (2000). The relationship between learning orientation, market orientation and organisational performance, paper presented at the Australian \& New Zealand Marketing Academy Conference, Queensland, Australia.

Hartono, Jogiyanto. (2004). Metodologi Penelitian Bisnis. Salah Kaprah dan Pengalaman-Pengalaman. BPFE, Yogyakarta. 
Henard, D.H. and Szymanski, D.M. (2001). Why some new products are more successful than others. Journal of Marketing Research, Vol. 38, No. 3, pp. 362-75. http://dx.doi.org/10.1509/jmkr.38.3.362.18861

Hult, G.T.M., Hurley, R.F. and Knight, G.A. (2004). Innovativeness: its antecedents and impact on business performance. Industrial Marketing Management, Vol. 33, No. 5, pp. 429-38. http://dx.doi.org/10.1016/j.indmarman.2003.08.015

Hunt, S.D. and Morgan, R.M. (1995). The Comparative Advantage Theory of Competition. Journal of Marketing, Vol. 59, No. 2, pp.1-15. http://dx.doi.org/10.2307/1252069

Hurley, R.F. and Hult, G.T.M. (1998). Innovation, market orientation, and organizational learning: an integration and empirical examination. Journal of Marketing, Vol. 62, No. 3, pp. 42-54. http://dx.doi.org/10.2307/1251742

Jaworski, B.J. and Kohli, A.K. (1993). Market orientation: antecedents and consequences. Journal of Marketing, Vol. 57, No. 3, pp. 53-70. http://dx.doi.org/10.2307/1251854

Kara, Ali John E. Spillan and Oscar W. Deshields, Jr. (2005). An Empirical Investigation of The Effect of A Market Orientation on Business Performance: A Study of Small-Sized Service Retailers Using MARKOR Scale. Journal of Small Business Management, Vol. 43, No. 2, pp.105-118.

Keskin, Halit. (2006). Market orientation, learning orientation and innovation capability in SMES: an extended model. European Journal of Innovation Management, Vol. 9, No. 4, pp.396-417. http://dx.doi.org/10.1108/14601060610707849

Kitchell, S. (1995). Corporate culture, environmental adaptation, and innovation adoption: a qualitative/quantitative approach. Journal of the Academy of Marketing Science, Vol. 23, No. 3, pp. 195-205. http://dx.doi.org/10.1177/0092070395233004

Kohli, A.K. and Jaworski, B.J. (1990). Market orientation: the construct, research propositions, and managerial implications. Journal of Marketing, Vol. 54, No. 2, pp. 1-18. http://dx.doi.org/10.2307/1251866

Lado, Nora and Olivares, Albert M, (2001). Exploring the Link Between Market Orientation And Innovation In The European and US Insurance Markets. International Marketing Review, Vol. 18. No. 2, pp. 130-144. http://dx.doi.org/10.1108/02651330110389972

Lee, Tie.T. and Tsai, Hsin Ju. (2005). The effect of business operation mode on market orientation, learning orientation and innovativeness. Industrial Management \& data System, Vol. 105, No. 3, pp.325-348. http://dx.doi.org/10.1108/02635570510590147

Lin, Chien Huang., Peng, Ching Huai and Kao, Danny T. (2008). The innovativeness effect of market orientation and learning orientation on business performance. International Journal on Manpower, Vol. 29, No. 8, pp.725-772. http://dx.doi.org/10.1108/01437720810919332

Matsuno, K. and Mentzer, J.T. (2000). The Effects of Strategy Type on The Market Orientattion-Performance Relationship. Journal of Marketing, Vol. 64, (October). pp. 1-16. http://dx.doi.org/10.1509/jmkg.64.4.1.18078

Mullen, T.P. and Lyles, M.A. (1993). Toward improving management development's contribution to organizational learning. Human Resource Planning, Vol. 16, No. 2, pp. 35-49.

Narver, J.C. and Slater, S.F. (1990). The effect of a market orientation on business profitability. Journal of Marketing, Vol. 54, No. 4, pp. 20-35. http://dx.doi.org/10.2307/1251757

Pelham, A.M. (2000). Market orientation and other potential influences on performance in small and medium-sized manufacturing firms. Journal of Small Business Management, Vol. 38, No. 1, pp. 48-67.

Perin, M.G. and Sampaio, C.H. (2003). The relationship between learning orientation and innovation, paper presented at the European Marketing Academy Conference, Glasgow, UK.

Sinkula. J.M, Baker.M.R and Noordewier. T. (1997). A Framework For Market-Based Organizational Learning: Linking Values, Knowledge, and Behaviour. Journal of the Academy of Marketing Science, Vol. 25, No. 4, pp. 305-318. http://dx.doi.org/10.1177/0092070397254003

Slater, S. (1997). Market Orientation at the Beginning of a New Millenium. Managing Service Quality, Vol. 11, No. 4, pp. 230-232. http://dx.doi.org/10.1108/EUM0000000005609

Slater, S.F. and Narver, J.C. (1994). Does competitive environment moderate the market orientation-performance relationship? Journal of Marketing, Vol. 58, No. 1, pp. 46-55. http://dx.doi.org/10.2307/1252250

Slater, S.F. and Narver, J.C. (1995). Market orientation and the learning organization. Journal of Marketing, Vol. 59, No. 3, pp. 63-74. http://dx.doi.org/10.2307/1252120 
Slater, S.F. and Narver, J.C. (1999). Research notes and communications: market-oriented is more than being customer-led. Strategic Management Journal, Vol. 20, No. 12, pp. 1165-8. http://dx.doi.org/10.1002/(SICI)1097-0266(199912)20:12<1165::AID-SMJ73>3.0.CO;2-\#

Speed, R., and Smith. (1993). Customers, Strategy and Performance. International Journal of Bank Marketing, Vol. 11, No. 5, pp. 3-11. http://dx.doi.org/10.1108/02652329310039609

Sujan, Harish, Weitz, Barton A. and Kumar Nirmala. (1994). Learning Orientation, Working Smart, and Effective Selling. Journal of Marketing, Vol. 58. (July) pp.39-52. http://dx.doi.org/10.2307/1252309

Verhees, F.J.H.M. and Meulenberg, M.T.G. (2004). Market orientation, innovativeness, product innovation, and performance in small firms. Journal of Small Business Management, Vol. 42, No. 2, pp. 134-54. http://dx.doi.org/10.1111/j.1540-627X.2004.00102.x

Zhang, Q., Lim, J-S. and Cao, M. (2004). Innovation-driven learning in new product development: a conceptual model. Industrial Management \& Data Systems, Vol. 104, No. 3, pp. 252-261. http://dx.doi.org/10.1108/02635570410525799

\section{Appendix: 1}

MO1 : The company seeks to create value-added customer product.

$\mathrm{MO} 2$ : Companies trying to understand the needs of consumers.

MO3 : The company strives to provide customer satisfaction

MO4 : There have been attempts by companies to measure customer satisfaction.

MO5 : The Company provides after-sales service for customers.

MO6 : Salesperson sharing of information about the company's competitors.

MO7 : The company responded quickly to the actions of competitors.

MO8 : Companies always respond to competitor strategies undertaken.

MO9 : The company has a target to create the product competitiveness.

MO10 : There is coordination across the inside of the company.

MO11 : Inter part in company share information.

MO12 : There is cooperation between divisions in formulating marketing strategy.

MO13 : All parts in our company participated in the creation of added value for customers.

LO1 : The Company seeks to improve the capabilities and abilities.

LO2 : The Company seeks to improve employee skills.

LO3 : The company develops mutual understanding and mutual trust among employees.

LO4 : The company strives to improve employee skills.

LO5 : The company encourages cooperation between process-oriented staff.

LO6 : The company strives to improve employees' way of thinking changes.

LO7 : Companies encourage employees to take risk

IN1 : The company always release products / services each year.

IN2 : Companies are always looking for new ways of doing business

IN3 : Companies are always trying to try new ideas.

IN4 : The company always tries to be first in marketing their products.

IN5 : Innovation is perceived by our company as being too risky (inv)

BP1 : Compared to previous years, our products reach a wider market.

BP2 : Compared to previous years, our company increase product sales.

BP3 : Compared to previous years corporate profits have increased.

BP4 : Compared to previous years, the level of complaints from customers decreased.

BP5 : Compared to previous years, the number of employees has increased.

BP6 : Compared to previous years, the number of our customers has increased. 
Table 1. Validity dan Reliability Test

\begin{tabular}{|c|c|c|c|}
\hline Variable & Indicators & Factor Loading & Reliability \\
\hline \multirow[t]{13}{*}{ Market Orientation } & Mo1 & 0.747 & \multirow{13}{*}{$\begin{array}{l}\text { Construct Reliability }=0.986 \\
\text { Variance Extrace }=0.845\end{array}$} \\
\hline & Mo2 & 0.740 & \\
\hline & Mo3 & 0.730 & \\
\hline & Mo4 & 0.751 & \\
\hline & Mo5 & 0.690 & \\
\hline & Mo6 & 0.596 & \\
\hline & Mo7 & 0.741 & \\
\hline & Mo8 & 0.764 & \\
\hline & Mo9 & 0.820 & \\
\hline & Mo10 & 0.638 & \\
\hline & Mo11 & 0.626 & \\
\hline & Mo12 & 0.625 & \\
\hline & Mo13 & 0.720 & \\
\hline \multirow{7}{*}{$\begin{array}{l}\text { Learning } \\
\text { Orientation }\end{array}$} & Lo1 & 0.901 & \multirow{7}{*}{$\begin{array}{l}\text { Construct Reliability }=0.981 \\
\text { Variance Extrace }=0.886\end{array}$} \\
\hline & Lo2 & 0.914 & \\
\hline & Lo3 & 0.700 & \\
\hline & Lo4 & 0.868 & \\
\hline & Lo5 & 0.641 & \\
\hline & Lo6 & 0.811 & \\
\hline & Lo7 & 0.508 & \\
\hline \multirow[t]{5}{*}{ Innovativeness } & In1 & 0.779 & \multirow{5}{*}{$\begin{array}{l}\text { Construct Reliability }=0.994 \\
\text { Variance Extrace }=0.975\end{array}$} \\
\hline & In2 & 0.926 & \\
\hline & In3 & 0.927 & \\
\hline & In4 & 0.857 & \\
\hline & In5 & 0.272 (Not Valid) & \\
\hline \multirow{6}{*}{$\begin{array}{l}\text { Business } \\
\text { Performance }\end{array}$} & Bp1 & 0.782 & \multirow{6}{*}{$\begin{array}{l}\text { Construct Reliability }=0.987 \\
\text { Variance Extrace }=0.939\end{array}$} \\
\hline & Bp2 & 0.946 & \\
\hline & $\mathrm{Bp3}$ & 0.942 & \\
\hline & Bp4 & 0.249 (Not Valid) & \\
\hline & $\mathrm{Bp} 5$ & 0.692 & \\
\hline & Bp6 & 0.713 & \\
\hline
\end{tabular}


Table 2. Regression Weight

\begin{tabular}{|c|c|c|c|c|c|}
\hline & Estimate & S.E. & C.R. & $\mathrm{P}$ & Label \\
\hline Learning_Orientation $\leftarrow$ Market_Orientation & 0.443 & 0.080 & 5.564 & 0.000 & $* * *$ \\
\hline$\leftarrow$ Learning_Orientation & 1.117 & 0.295 & 3.786 & 0.000 & $* * *$ \\
\hline$\leftarrow$ Market_Orientation & 0.600 & 0.149 & 4.022 & 0.000 & $* * *$ \\
\hline Business Performance $\leftarrow$ Innovativness & 0.281 & 0.091 & 3.091 & 0.002 & $* * *$ \\
\hline Business Performance $\leftarrow$ Learning_Orientation & 0.225 & 0.228 & 0.985 & 0.325 & \\
\hline Business Performance $\leftarrow$ Market_Orientation & 0.242 & 0.131 & 1.840 & 0.066 & * \\
\hline Mo1 $\leftarrow$ Market_Orientation & 1.000 & & & & $* * *$ \\
\hline Mo $2 \leftarrow$ Market_Orientation & 0.815 & 0.089 & 9.175 & 0.000 & $* * *$ \\
\hline Mo3 $\leftarrow$ Market_Orientation & 0.656 & 0.073 & 8.977 & 0.000 & $* * *$ \\
\hline Mo4 $\leftarrow$ Market_Orientation & 0.967 & 0.101 & 9.596 & 0.000 & $* * *$ \\
\hline Mo5 $\leftarrow$ Market_Orientation & 1.003 & 0.120 & 8.352 & 0.000 & $* * *$ \\
\hline Mo6 $\leftarrow$ Market_Orientation & 0.762 & 0.108 & 7.072 & 0.000 & $* * *$ \\
\hline Mo7 $\leftarrow$ Market_Orientation & 1.227 & 0.131 & 9.389 & 0.000 & $* * *$ \\
\hline Mo8 $\leftarrow$ Market_Orientation & 1.218 & 0.126 & 9.657 & 0.000 & $* * *$ \\
\hline Mo9 $\leftarrow$ Market_Orientation & 1.161 & 0.110 & 10.510 & 0.000 & $* * *$ \\
\hline Mo10 $\leftarrow$ Market_Orientation & 0.768 & 0.100 & 7.663 & 0.000 & $* * *$ \\
\hline Mo11 $\leftarrow$ Market_Orientation & 0.796 & 0.105 & 7.602 & 0.000 & $* * *$ \\
\hline Mo12 $\leftarrow$ Market_Orientation & 0.856 & 0.110 & 7.763 & 0.000 & $* * *$ \\
\hline Mo13 $\leftarrow$ Market_Orientation & 0.938 & 0.105 & 8.938 & 0.000 & $* * *$ \\
\hline Lo7 $\leftarrow$ Learning_Orientation & 1.000 & & & & $* * *$ \\
\hline Lo6 $\leftarrow$ Learning_Orientation & 1.569 & 0.247 & 6.351 & 0.000 & $* * *$ \\
\hline Lo5 $\leftarrow$ Learning_Orientation & 1.207 & 0.216 & 5.586 & 0.000 & $* * *$ \\
\hline Lo4 $\leftarrow$ Learning_Orientation & 1.502 & 0.230 & 6.537 & 0.000 & $* * *$ \\
\hline Lo3 $\leftarrow$ Learning_Orientation & 1.088 & 0.184 & 5.907 & 0.000 & $* * *$ \\
\hline Lo $2 \leftarrow$ Learning_Orientation & 1.652 & 0.249 & 6.644 & 0.000 & $* * *$ \\
\hline Lo1 $\leftarrow$ Learning_Orientation & 1.670 & 0.253 & 6.599 & 0.000 & $* * *$ \\
\hline In $4 \leftarrow$ Innovativness & 1.076 & 0.091 & 11.768 & 0.000 & $* * *$ \\
\hline In $3 \leftarrow$ Innovativness & 1.138 & 0.086 & 13.260 & 0.000 & $* * *$ \\
\hline In $2 \leftarrow$ Innovativness & 1.050 & 0.080 & 13.173 & 0.000 & $* * *$ \\
\hline In $1 \leftarrow$ Innovativness & 1.000 & & & & $* * *$ \\
\hline Bp1 $\leftarrow$ Business_Performance & 1.000 & & & & $* * *$ \\
\hline $\mathrm{Bp} 2 \leftarrow$ Business_Performance & 1.280 & 0.095 & 13.520 & 0.000 & $* * *$ \\
\hline Bp3 $\leftarrow$ Business_Performance & 1.337 & 0.099 & 13.494 & 0.000 & $* * *$ \\
\hline Bp5 $\leftarrow$ Business_Performance & 1.131 & 0.123 & 9.159 & 0.000 & $* * *$ \\
\hline Bp6 $\leftarrow$ Business_Performance & 1.002 & 0.105 & 9.559 & 0.000 & $* * *$ \\
\hline
\end{tabular}




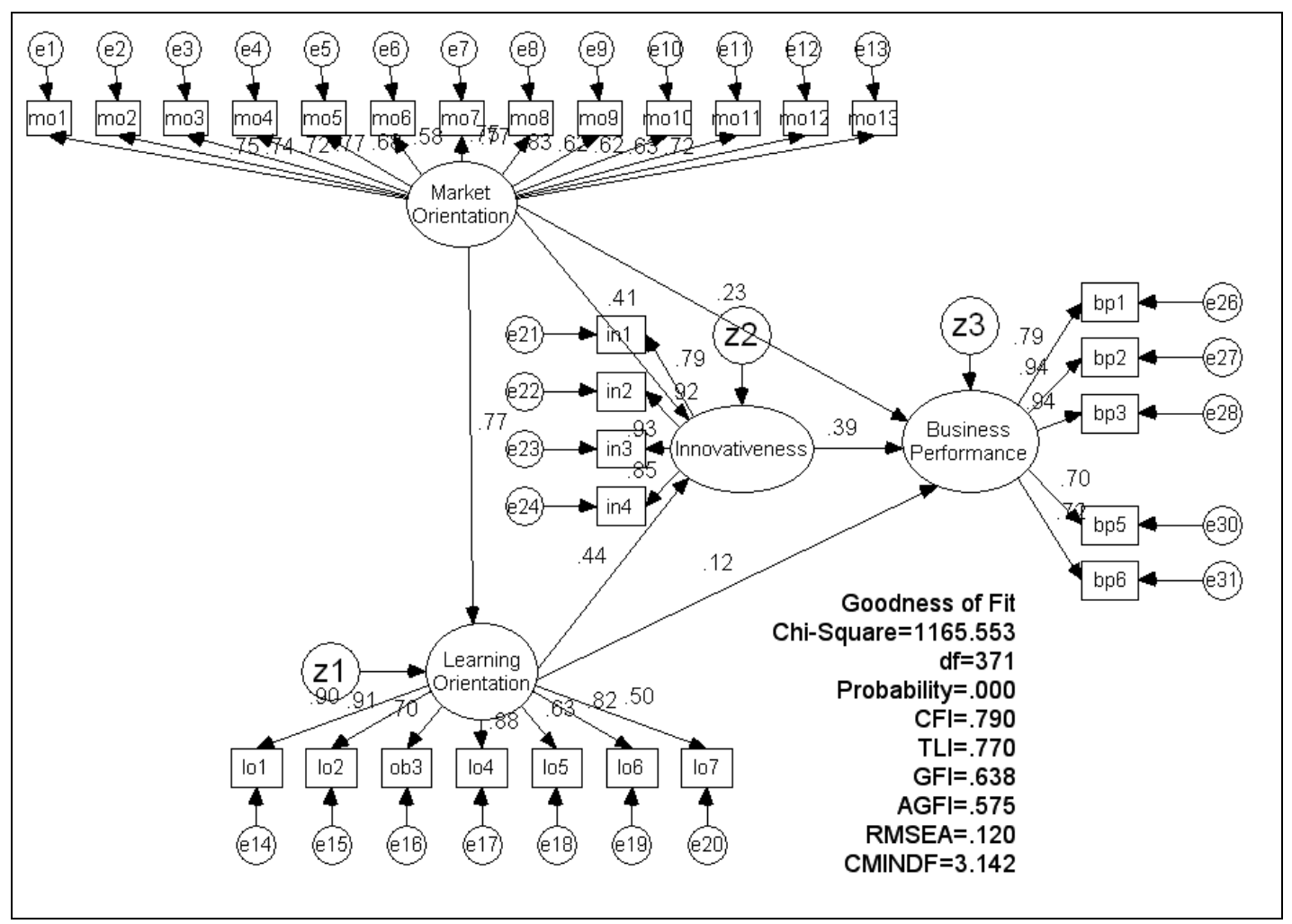

Figure 1. Research Model 